\author{
K.A. Nurlybaeva*, A.M. Aitkulov, G. Zh. Mukasheva, G.M. Tykezhanova \\ Karagandy University of the name of academician E.A. Buketov, Kazakhstan \\ *Corresponding author: kunduz09@mail.ru
}

\title{
Composition of chemical elements in the biosubstrate (hair) of children of the Karaganda region
}

\begin{abstract}
In the article we studied chemical elements in the hair of children as a form of environmental monitoring of metals in a given area, since one of the objective indicators of the ecological and hygienic well-being of a territory is the status of trace elements as the most sensitive part of the population, especially children. Many foreign scientific studies have shown that a hair sample is a good indicator of a negative technogenic impact on humans, and it is known that the unfavorable state of children characterizes the ecogeochemical features of the area, so we took into account the accumulation of trace elements in the hair. The study showed an increase in lead and cadmium and a decrease in zinc, copper and chromium.
\end{abstract}

Keywords: children, health, heavy metals, hair, toxic trace elements, chromium, zinc, manganese.

\section{Introduction}

According to modern scientific research, each pathology is characterized by certain deviations in the elemental status. This "spontaneous nature" indicates that the direct presence of individual elements can cause any disease. According to some authors, a change in the distribution of trace elements (TE) among body tissues and their quantitative changes during the development of any pathological condition should be considered as a manifestation of compensatory defense mechanisms or a violation of regulatory systems necessary for normal metabolism. These changes can be a diagnostic test for any disease.

In the scientific works of foreign scientists it is written that hair is a good indicator as a model for studying the negative impact of man-made influences on humans [1]. For diagnostic purposes heavy metals are often found in blood, urine, hair, and nails. According to some studies, the content of heavy metals (HM) in hair often does not increase, because HM usually accumulate in the liver, kidneys and bone tissue. However, when we find an increase in the content of heavy metals in hair we can talk about its enormous effect on the human body.

Despite the fact that in recent years extensive research has been carried out to obtain valuable information about the elemental composition of hair of people living in different regions of America, Europe and Russia, there is a need to develop the interpretation of data in the field of medical elementology. To assess the elementary status of children living in the cities of the Karaganda region and to analyze not only the absolute values of concentrations, but also their relationship by calculating various coefficients and obtaining imbalances, in this work we have combined a number of integral indices used by elementologists: E.P. Yanin (2011), A.V. Skalny (2004), N.A. Agadzhanyan, A.V. Skali, E.S. Berezkina (2016) and others [2-6].

Numerous studies reveal significant functional changes in the quantitative composition of hair, taking into account the regional characteristics of the ecological situation in terms of the content of micronutrients, and prove that such studies are possible [2].

It is known that the child's organism is practically not influenced by production factors, to a lesser extent socio-economic, and the spontaneous state of children characterizes the ecogeochemical features of the area. When assessing the prevalence of micronutrient imbalances due to the limited number of officially developed chemical elements, indicator values are usually used based on data on biologically acceptable levels or upper and lower limits of the physiological composition of chemical elements.

\section{Methodology}

Due to the lack of approved reference values for TE concentration in hair among the population of the Republic of Kazakhstan the average Russian values were used as reference values for HM concentration in hair by analyzing and interpreting the data "Dr. Skalny's method" (No. 20002471 dated November 6, 1997) $[3,7,8]$. 


\section{Results and discussion}

We used an estimate of individual hair composition ratios for the lower and upper BRD based on the reference values provided by Russian scientists $[7,9]$ and then divided the studies by percentage. Data on the degree of load on essential, conditionally toxic and toxic MEs are given in the table below. The estimates of the content of these toxic substances in the human body are given (Table 1).

$\mathrm{Table} 1$

\section{Control values of the main, conditionally toxic and toxic micronutrients in children's hair $(\mu \mathrm{g} / \mathrm{g})$}

\begin{tabular}{|c|c|c|}
\hline $\begin{array}{c}\text { Chemical } \\
\text { elements }\end{array}$ & Centile averages & Centile averages \\
\hline $\mathrm{Cu}$ & $8-15^{*}$ & $7.5-80^{*}$ \\
\hline $\mathrm{Fe}$ & $10-25^{*}$ & $5.0-25^{*}$ \\
\hline $\mathrm{Zn}$ & $140-220^{*}$ & $100-250^{*}$ \\
\hline $\mathrm{Mn}$ & $0.1-1.0^{*}$ & $0.2-4.4^{*}$ \\
\hline $\mathrm{Cr}$ & $0.1-2.0^{*}$ & $0.1-2.0^{*}$ \\
\hline $\mathrm{Co}$ & $0.01-0.5^{*}$ & $0.01-1.8^{*}$ \\
\hline
\end{tabular}

Note. $*$ - credibility $\mathrm{p}<0.05$

In children living in Karaganda $\mathrm{Pb}$ (2003) was 3.76 times higher than the physiological norm proposed by A.V. Skalny, and in Balkhash it was 1.7 times higher (Table 2).

\section{Average content of toxic and conditionally toxic elements in the hair of children of the Karaganda region $(\mathrm{M} \pm \mathrm{m})$}

\begin{tabular}{|c|c|c|c|c|c|}
\hline \multirow{3}{*}{ Cities } & \multirow{3}{*}{$\begin{array}{c}\text { Amount } \\
\text { of children } \\
(420)\end{array}$} & $\mathrm{Ni}$ & As & $\mathrm{Pb}$ & $\mathrm{Cd}$ \\
\hline & & \multicolumn{4}{|c|}{ physiological norm $(\mu \mathrm{g} / \mathrm{g})$} \\
\hline & & $0.1-2.0$ & $0.005-0.10$ & $0.1-5.0$ & $0.05-0.25$ \\
\hline Karaganda & $n=100$ & $0.21 \pm 0.02$ & $0.04 \pm 0.003$ & $18.8 \pm 0.1^{*}$ & $0.05 \pm 0.016$ \\
\hline Temirtau & $n=80$ & $0.9 \pm 0.02$ & $0.1 \pm 0.02$ & $6.2 \pm 0.1 *$ & $0.30 \pm 0.14 *$ \\
\hline Balkhash & $n=80$ & $1.2 \pm 0.1$ & $0.07 \pm 0.005$ & $8.54 \pm 1.5^{*}$ & $0.05 \pm 0.1$ \\
\hline Zhezkazkan & $n=80$ & $1.1 \pm 0.1$ & $0.1 \pm 0.08$ & $8.24 \pm 3.04 *$ & $0.91 \pm 0.011$ \\
\hline Abay & $n=80$ & $0.8 \pm 0.02$ & $0.06 \pm 0.02$ & $0.110 \pm 0.01$ & $0.073 \pm 0.028$ \\
\hline
\end{tabular}

Note. $*$ - credibility $\mathrm{p}<0.05$

Lead levels in children living in Zhezkazgan are 1.6 times higher than normal, and in children living in Temirtau they are 1.24 times higher than normal. Here it should be noted that the results of our study are consistent with the data on the content of microelements in the hair of children [8].

According to the correlation-regression analysis, the amount of lead in the blood taken by the WHO $(20 \mu \mathrm{g} / 100 \mathrm{ml})$ was determined in the case of non-professional exposure, the amount of metal in the hair was about $40 \mu \mathrm{g} / \mathrm{g}$. On its website WHO lists lead as one of the top 10 chemicals with serious health risks and is developing measures to protect children's health from exposure to lead $[10,11]$.

According to Skalny, Cd is an important candidate for essentiality. It is known that this element is considered important; if the human body does not have or has an insufficient amount of the element, the body stops growing and developing, it cannot fulfill its biological cycle, including the ability to reproduce. The introduction of the missing element eliminates the symptoms of its deficiency and restores the vitality of the organism. According to other scientific publications, $\mathrm{Cd}$ is an element that should not be present in the human body, its acceptable levels are minimal. Analysis of the results showed that a slight increase in $\mathrm{Cd}$ in the hair of children from Temirtau was $0.30 \pm 0.14$ ( $p<0.05$ ), an increase in Cd was observed in the hair of children from Balkhash and amounted to $1.5 \pm 0.1(\mathrm{p}<0.05)$, the increase in $\mathrm{Cd}$ in the hair of children in the city of Zhezkazgan was $0.91 \pm 0.011$.

Conditionally toxic elements, such as $\mathrm{Ni}$ and As, were found in the hair of children in the cities of the Karaganda region within the physiological norm.

The main reason for the lack of ME in the body may be an unbalanced ratio of various food components that increase or decrease the absorption of ME, as well as an insufficient level of ME consumption with their 
loss in the process of survival. Only a change in the ratio of ME in the diet can significantly affect the absorption of certain trace elements.

To date, we do not have enough knowledge about the peculiarities of IE metabolism in the body under the influence of various environmental factors, the composition of IE in food, as well as some norms of IE consumption, balance and types of their interaction in the body. how to use a certain level of drugs.

In this regard, studies of the essential composition of hair of children in the cities of the Karaganda region have been continued. The average content of $\mathrm{Cr}$ in hair of children living in the studied cities of the Karaganda region was determined within the physiological norm (Table 3).

Table 3

Average content of the main microelements in the hair of children of the Karaganda region (M $\pm m$ )

\begin{tabular}{|l|c|c|c|c|}
\hline \multirow{2}{*}{ Cities } & \multirow{2}{*}{$\begin{array}{c}\text { Amount } \\
\text { of children } \\
\end{array}$} & $(420)$ & Cr & \multicolumn{2}{c|}{ Cu } & $\mathrm{Zn}$ \\
\cline { 3 - 5 } & $n=100$ & $0.1-2.0^{*}$ & $7.5-80$ & $100-250$ \\
\hline Karaganda & $n=80$ & $0.092 \pm 0.005^{*}$ & $6.059 \pm 0.019^{*}$ & $94.0 \pm 0.41^{*}$ \\
\hline Temirtau & $n=80$ & $0.072 \pm 0.006^{*}$ & $3.21 \pm 0.04$ & $75.7 \pm 4.6^{*}$ \\
\hline Balkhash & $n=80$ & $0.056 \pm 0.002^{*}$ & $3.38 \pm 0.28^{*}$ & $72.0 \pm 0.29^{*}$ \\
\hline Zhezkazkan & $n=80$ & $0.557 \pm 0.241$ & $5.5 \pm 0.17$ & $81.0 \pm 3.9^{*}$ \\
\hline Abay & & $20.7 \pm 0.5$ & $162.347 \pm 4.5$ \\
\hline
\end{tabular}

Note. $*$ - credibility $\mathrm{p}<0.05$

The results of the study showed that the content of $\mathrm{Cr}$ in the hair of children in industrial cities of the region is below the norm. The $\mathrm{Cu}$ content required for the maintenance of the organism and its growth also showed low and very low values, which in children of the city of Karaganda were 3.45 times lower than the "control" level and 1.23 times lower than the physiological norm. The amount of $\mathrm{Cu}$ in the hair of children in Temirtau was 2.3 times lower than the norm, the concentration of $\mathrm{Cu}$ in the hair of children in Zhezkazgan was 1.36 times lower. It was found that the amount of $\mathrm{Cu}$ in children in Balkhash was 2.2 times lower than the norm $(\mathrm{p}<0.05)$.

However, in all studied groups the $\mathrm{Cu}$ concentration had significant individual deviations. The symptoms of $\mathrm{Cu}$ deficiency are specific and lead to increased fatigue, general weakness, irritability, decreased emotional background, weight loss, diarrhea, impaired carbohydrate metabolism, anemia, hair and skin damage, and visual impairment. Low concentrations of inorganic copper salts entering the body cause hemolysis (destruction of red blood cells). A clear relationship has been established between the copper concentration and the degree of ceruloplasmin activity, since the balance between oxidative processes and endogenous antioxidants is a particular defense against cancer. The development of tumor processes affects the activity of ceruloplasmin and the concentration of copper and zinc in the blood serum of patients with lung cancer. Changes in the activity of $\mathrm{Cu} / \mathrm{Zn}$ superoxide dismutase (SOD) have been found for many tumors [9].

Studies of the content of zinc in the hair of children in Karaganda, Balkhash, Temirtau and Zhezkazgan show that the deficiency of this element is $1.06 ; 3.47 ; 3.3$ and 3 times lower. Here it should be noted that lead can accumulate in the body due to zinc deficiency. The concentration of $\mathrm{Zn}$ in the hair of Abai children was $162347 \pm 4.5$, which is normal. Zinc has been shown to stimulate the production of antibodies and is responsible for maintaining the immune system, is part of many enzymes and is involved in many metabolic processes in the body.

The need for manganese and iron varies throughout life and depends on gender, age, as well as on the physiological state of the body. Both the deficiency and the excess of these elements negatively affect human health. Residents of industrial cities may be exposed to excessive amounts of manganese and iron in the inhaled air or drinking water.

The problem of subclinical chronic poisoning with these xenobiotics is of great concern [10]. Continuing the study of the composition of essential ME in the hair of children from the cities of the Karaganda region, we found that the average Fe content in the hair of all examined children living in the cities of the Karaganda region was within the physiological norm (Table 4). 
Table 4

Average content of the main microelements in the hair of children of the Karaganda region $(\mathrm{M} \pm \mathrm{m})$

\begin{tabular}{|c|c|c|c|c|}
\hline \multirow{3}{*}{ Cities } & \multirow{3}{*}{$\begin{array}{c}\text { Amount } \\
\text { of children } \\
(420)\end{array}$} & $\mathrm{Fe}$ & $\mathrm{Mn}$ & $\mathrm{Co}$ \\
\hline & & \multicolumn{3}{|c|}{ physiological norm $(\mu \mathrm{g} / \mathrm{g})$} \\
\hline & & $5.0-25$ & $0.2-4.4$ & $0.01-1.8$ \\
\hline Karaganda & $n=100$ & $13.819 \pm 0.69$ & $0.285 \pm 0.008$ & $0.35 \pm 0.003$ \\
\hline Temirtau & $n=80$ & $7.46 \pm 0.67$ & $0.29 \pm 0.009$ & $0.34 \pm 0.002$ \\
\hline Balkhash & $n=80$ & $5.13 \pm 0.14$ & $0.24 \pm 0.02$ & $0.045 \pm 0.004$ \\
\hline Zhezkazkan & $n=80$ & $6.95 \pm 0.84$ & $0.25 \pm 0.061$ & $0.05 \pm 0.04$ \\
\hline Abay & $n=80$ & $20.7 \pm 1.8$ & $0.93 \pm 0.05$ & $0.05 \pm 0.01$ \\
\hline
\end{tabular}

At physiological concentrations manganese protects against oxidative stress, and an excess of this trace element affects the developing of central nervous system as an oxidizing agent. Children exposed to excessive amounts of manganese in the environment suffer from behavioral disorders, including learning disabilities. The average amount of $\mathrm{Mn}$ in the hair of all examined children living in the cities of the Karaganda region was determined within the physiological norm.

Measuring cobalt in hair is an indirect method for assessing the level of cobalt in the body, which is a good alternative to measuring the level of this element in blood and urine. As with blood tests, hair cobalt concentration is a good indicator of total body cobalt levels [7-10]. Cobalt can enter the hair not only from internal sources, but also as a result of "contamination" of the hair from outside, for example, when washing hair with water.

We know that the hair exhibits an average concentration of compounds over a fairly long period of time, while the concentration in blood and urine fluctuates for a short time. The results of the study showed that the content of cobalt in the hair of children in the region varies approximately as much as it is necessary to maintain physiological norms.

\section{Conclusion}

Chemical environmental factors are often found in concentrations that upset the dynamic balance between a biological object and the environment, and also cause functional and organic damage at different levels of organization of living matter. The concept of "toxicity" has expanded significantly in recent years and acquired many aspects. Toxicity can be characterized as a cause of a disease of chemical etiology (poisoning) and a factor causing chemical damage to tissues (a typical pathological process), the consequences of which form the corresponding pathological condition. This means the importance of studying the mechanisms of general (complex) and individual toxicity, which ultimately determines the nature of the pathological process and clinical manifestations of chemical intoxication, its long-term consequences, which can significantly contribute to the health of children.

\section{References}

1 Pearce E.N. Iodine deficiency in children / E.N. Pearce // Endocr Dev. — 2014. — Vol. 26. — P. 130-138.

2 Янин Е.П. Особенности накопления тяжелых металлов в волосах детей в условиях промышленного города / Е.П. Янин // Экологическая экспертиза. — 2011. - № 4. - С. 112-116.

3 Скальный А.В. Химические элементы в физиологии и экологии человека / А.В. Скальный. - М., 2004. - 215 с.

4 Агаджанян Н.А. Референтные значения содержания химических элементов в волосах взрослых жителей Республики Татарстан / Н.А. Агаджанян, А.В. Скальный, Е.С. Березкина // Экология человека. — 2016. — № 4. — С. 38-44.

5 Луговая Е.А. Региональные показатели содержания макро- и микроэлементов в организме жителей г. Магадана: науч.практ. реком. / Е.А. Луговая, Е.А. Степанова. - Магадан: ИП «Чингилян», 2019. — 27 с.

6 Агаджанян Н.А. Элементный портрет человека: заболеваемость, демография и проблема управления здоровьем нации / Н.А. Агаджанян, А.В. Скальный, В.Ю. Детков // Экология человека. — 2013. — № 11. — С. 3-12.

7 Майманова Т.М. Содержание тяжелых металлов и микроэлементов в волосах / Т.М. Майманова, Л.С. Тютюкова // Геохимия ландшафтов к 100-летию А.И. Перельмана: докл. Всерос. науч. конф. — М., 2016. — С. 335-337.

8 Любченко П.Н. Скрининговые методы для выявления групп повышенного риска среди рабочих, контактирующих с токсичными химическими элементами: метод. реком. / П.Н. Любченко, Б.А. Ревич. — М., 1988. — 24 с. 
9 Нотова С.В. Необходимость учета региональных особенностей в моделировании процессов межэлементных взаимодействий в организме человека / С.В. Нотова, С.А. Мирошников, И.П. Болодурина и др. // Вестн. ОГУ. — 2006. - № 2 . C. 59-63.

10 Кубасова Е.Д. Физиологическая характеристика биоэлементного статуса и его влияние на состояние щитовидной железы детей Архангельской области: автореф. ... канд. биол. наук / Е.Д. Кубасов. — Архангельск, 2007. — 18 с.

11 Agis H. Monocytes do not make mast cells when cultured in the presence of SCF / H. Agis // J. Immunology. - 1993. Vol. 151(8). - P. 4221.

\title{
К.А. Нурлыбаева, А.М. Айткулов, Г.Ж. Мукашева, Г.М. Тыкежанова \\ Қарағанды облысы балаларының биосубстратындағы (шаштарындағы) химиялық элементтердің құрамы
}

\begin{abstract}
Мақалада аумақтың экологиялық және гигиеналық әл-ауқатының объективті көрсеткіштерінің бірі халықтың микронутриентті мәртебесі болып саналатын, әсіресе балалар болғандықтан аумақтағы металдарға экологиялық мониторинг жүргізу нысаны ретінде балалар шаштарындағы химиялық элементтер зерттелген. Көптеген шетелдік ғылыми жұмыстарда адамға техногендік әсердің жағымсыз тұстарын зерттеуде үлгі ретінде шаш сынамасы жақсы индикатор болып табылатындығы айтылған және балалардың элементтік жағдайы аумақтың экогеохимиялық ерекшеліктерін сипаттайтыны белгілі, сондықтан да инвасивсіз әдіспен шашта микроэлементтердің жинақталуы қарастырылған. Зерттеу нәтижесінде қорғасын мен кадмий мөлшерінің артқаны және мырыш, мыс және хром мөлшерінің төмендеуі анықталды.
\end{abstract}

Кілт сөздер: балалар, денсаулық, ауыр металдар, шаш, улы микроэлементтер, хром, мырыш, марганец.

\section{К.А. Нурлыбаева, А.М. Айткулов, Г.Ж. Мукашева, Г.М. Тыкежанова \\ Состав химических элементов в биосубстрате (волосах) детей Карагандинской области}

\begin{abstract}
В статье изучено содержание химических элементов в волосах детей как форма экологического мониторинга металлов в данной местности, поскольку одним из объективных показателей экологического и гигиенического благополучия местности является микронутриентный статус населения, особенно детей. Результаты зарубежных научных исследований показали, что тест на волосы является хорошим индикатором негативного влияния техногенных факторов на человека, и известно, что стихийное состояние детей характеризует экогеохимические особенности местности, поэтому рассмотрено накопление микроэлементов в волосах. Исследование выявило увеличение в них содержания свинца и кадмия и снижение цинка, меди и хрома.
\end{abstract}

Ключевые слова: дети, здоровье, тяжелые металлы, волосы, токсичные микроэлементы, хром, цинк, марганец.

\section{References}

1 Pearce, E.N. (2014). Iodine deficiency in children. Endocr. Dev., 26; 130-138.

2 Yanin, E.P. (2011). Osobennosti nakopleniia tiazhelykh metallov v volosakh detei v usloviiakh promyshlennogo goroda [Peculiarities of accumulation of heavy metals in hair children in the conditions of the industrial city]. Ekologicheskaia ekspertiza Ecological expertise, 4; 112-116 [in Russian].

3 Skalnyi, A.V. (2004). Khimicheskie elementy $v$ fiziologii i ekologii cheloveka [Chemical elements in the human physiology and ecology]. Moscow [in Russian].

4 Agadzhanyan, N.A., Skal'nyi, A.V., \& Berezkina, E.S. (2016). Referentnye znacheniia soderzhaniia khimicheskikh elementov v volosakh vzroslykh zhitelei Respubliki Tatarstan [Reference values of chemical elements content in hair of adult residents of the Republic of Tatarstan]. Ekologiia cheloveka - Human ecology, 4; 38-44 [in Russian].

5 Lugovaya, E.A., \& Stepanova, E.M. (2019). Regionalnye pokazateli soderzhaniia makro- i mikroelementov v organizme zhitelei g. Magadana [Regional indicators of the content of macro- and trace elements in the body of residents of Magadan]. Magadan [in Russian].

6 Agadzhanyan, N.A., Skal'nyi, A.V., \& Detkov, V.Yu. (2013). Elementnyi portret cheloveka: zabolevaemost, demografiia i problema upravleniia zdorovem natsii [Elemental portrait of a person: morbidity, demography and the problem of managing the health of the nation]. Ekologiia cheloveka - Human ecology, 11; 3-12 [in Russian]. 
7 Maimanova, T.M., \& Tyutyukova, L.S. (2016). Soderzhanie tiazhelykh metallov i mikroelementov v volosakh [Content of heavy metals and microelements in hairs]. Geochemistry of landscape to the 100-year Anniversary of A.I. Perelman: Vserossiiskaia nauchnaia konferentsiia - All-Russian scientific conference. (p. 335-337). Moscow [in Russian].

8 Lyubchenko, P.N., Revich, B.A., \& Levchenko, I.I. (1988). Skriningovye metody dlia vyiavleniia grupp povyshennogo riska sredi rabochikh, kontaktiruiushchikh s toksichnymi khimicheskimi elementami [Screening methods to identify high-risk groups among workers in contact with toxic chemical elements: method]. Moscow [in Russian].

9 Notova, S.V., Miroshnikov, S.A., \& Bolodurina, I.P. (2006). Neobkhodimost ucheta regionalnykh osobennostei v modelirovanii protsessov mezhelementnykh vzaimodeistvii v organizme cheloveka [The need to take into account regional features in modeling the processes of inter-element interactions in the human body]. Vestnik OGU - Bulletin of OSU, 2; 59-63 [in Russian].

10 Kubasova, E.D. (2007). Fiziologicheskaia kharakteristika bioelementnogo statusa i ego vliianie na sostoianie shchitovidnoi zhelezy detei Arkhangelskoi oblasti [Physiological characteristic of bioelement status and its effect on the thyroid gland of children of the Arkhangelsk region]. Candidate's thesis. Arkhangelsk [in Russian].

11 Agis, H. (1993). Monocytes do not make mast cells when cultured in the presence of SCF. J. Immunology, 151 (8); 4221. 